\title{
THE FORMATION OF INSTITUTIONAL ENVIRONMENT OF AGRICULTURAL LAND CONSOLIDATION IN UKRAINE
}

\author{
Andriy POPOV ${ }^{1}$, \\ V.V. Dokuchaev National University of Kharkiv, Ukraine
}

\begin{abstract}
Every theory requires an application tool. Land consolidation is the multidisciplinary tool for sustainable rural development with its dynamic structure that gives possibilities getting the best solutions for land management decision. That is why the main purpose of the article is a theoretical study and development of scientific and practical recommendations concerning the formation of institutional environment of agricultural land consolidation in Ukraine. The subject of study is the formation of agricultural land consolidation. Methodology. The study used the following methods: dialectical, logical and abstract, system analysis (theoretical and methodological generalizations, defining the essence of the content of institutional environment of agricultural land consolidation). This paper identifies the role of the institutions in economic development and characterised the regulatory, procedural, distributive, informational, development and accumulation functions of agricultural land consolidation institution. As a novelty items offered and provided the detailed description of the main components of the institutional environment of agricultural land consolidation such as: traditional and mental, legal, causal, organizational and structural, and procedural. The essence of institutions of each of these components and their meaning and relationships are presented. Theoretically investigated that the formation of institutional mechanism of consolidation should be a symbiosis of both traditional and market institutions based on democratic principles under community participation. The article focuses on the feasibility of the formation of mechanism for monitoring the effectiveness of institutions. As the result of the study the author proposed to consider the institutional environment of agricultural land consolidation as a regulatory system harmonizing relations of the agricultural production, social and natural resources, designed to optimize the production, based on the actual requirements and restrictions of the existing institutes and institutions to guarantee a rational use of land resources. Practical implications. Analysis of current situation in Ukraine suggests that the urgent task is particularly not only to create, design and import of the land consolidation institutions but also to provide the diagnostic of their maturity and suitability for the current level of the land consolidation relations. This conclusion is supported with the lack of a specific state policy on development of land consolidation and distrust in government initiates. The author also provides a list of necessary actions required for the development of the agricultural land consolidation in Ukraine.
\end{abstract}

Key words: institutional environment, institutions, land consolidation, procedure, formation, organization.

JEL Classification: D02, O17, O43, P25, P37

\section{Introduction}

The world experience shows that one of the main factors that determine the level of func-tioning and developing of agricultural land consolidation in the framework of a sustainable rural development is its institutional environment. In Ukraine during the transitional period a definite structure of this environment have been formed, but this form has disorganised and unregulated version and so far has not yet led to the improvement of economic, social and environmental state of rural areas.

Nowadays, in the context of market institutions development an urgent task is to build up common rules for the agricultural land consolidation and as a result to arrange all its main elements such as objectives, functions, tasks, and justification of basic directions on order to establish an in-stitutional environment mechanism for land consolidation realisation.

Analysis of recent research and publications shows that Kilochko (2009), Martyn (2011), Tkachuk (2009), Tretyak (2002) and Shvorak (2008) partly paid attention to the problems of agri-cultural land consolidation development. At the international level Vitikainen (2004), van Dijk (2002, 2004), Sonnenberg (2002), Thomas (2004, 2006), Food and Agriculture Organization of the United Nations $(2003,2008)$ and others also studied this issue.

\footnotetext{
Corresponding author:

${ }^{1}$ Department of Land Management and Cadastre, Kharkiv National Agrarian University named after V.V. Dokuchayev.

E-mail: popov_andriy@knau.kharkov.ua
} 
However, in the works of these authors there is practically no comprehensive study of land consolidation institutional rearrangements. Despite the great scientific interest of professionals to the problems of institutional environment of agricultural land consolidation numerous theoretical, methodological and practical issues remain unsolved. The relevance of this research is confirmed with incompleteness of scientific development of organizational arrangements of the institutional environment of consolidation, from the one hand, and with the essential practical importance of this problem for the state - on the other hand.

The aim of paper is a theoretical study and development of the scientific and practical recommendations concerning the formation of institutional environment of agricultural land consolidation. The study used the following methods: dialectical, logical and abstract, system analysis (theoretical and methodological generalizations, defining the essence of the content of institutional environment of agricultural land consolidation).

\section{The role and functions of institutions}

The conditions of land consolidation development are significantly created with the institution. According to the new institutional economic theory the institutions are defined as behaviour rules, as regulatory principles that establish or, vice versa, prohibit some certain methods of the action (Melnyk, Vasina, Zheljuk, Popovich, 2011).

By the level of formalisation, the institutions are divided into formal and informal. The formal institutions include the written legislative regulations (for individual landowners, land users, non-governmental organizations are fixed with business contracts). The informal ones are presented with social norms (at the level of individual participants in land tenure are presented by business agreements).

Natural institutions are those which occur as an automatic reaction to the certain changes in the economic environment and non-natural ones are those which appear as a result of a purposeful human activity. The institutions that play a major role in the economic system are considered as basic (e.g, the institution of property, entrepreneurship, competition, etc.). Complementary institutions - are the institutions that are formed around the basic ones and have a supporting role in the economy.

The role of institutions in the economic development is related in the implementation of their functions. In the scientific literature such functions of institutions as: regulatory, procedural, distributive, informational, development and accumulation are distinguished. The institutions have an influence on the transformation of land tenure during land consolidation providing through the implementation of above-mentioned functions.

The regulatory function of institutions is in its ability for coordination, harmonization, management, cooperation, stratification (ordering of succession) of participants' interactions in land consolidation and to governance of their operations and development. The institutions regulate the activities of the interested parties in carrying out of land consolidation with means of the establishing the restriction in the set of available alternatives and determining the motives of their behaviour. The clearness of the rules in the sphere of land consolidation reduces the level of uncertainty for the participants in the market economy system and increases the degree of its awareness about the possible changes in the environment caused with the behaviours of the other actors. If land consolidation actors know the rules of activity, they have an opportunity to predict reactions of the opponents as to their own actions and can define the directions of their interaction with environment elements.

The procedural function of the institutions is in the formation of the regulations of economic behaviour of the land tenure actors concerning land consolidation with means of the norms and rules of an institutional framework. The distributive function is affected the distribution of economic re-sources in the society and represented by a system of the institutions and their activities. This feature of the institutions is found not only because of the impact on the trade turnover framework within a general economic conjuncture, but also because of the formation of the certain types of the institutions which provide the movement of resources under clearly defined rules. For example, the functioning of the institutions such as the State Land Cadastre and the State Registration Service, land surveying organizations, executive bodies on land resources, - is a code of rules by which there are land transactions and which must strictly be followed by the parties who have signed or intend to sign the agreements. Thus, the distributive function of the institutional system is realized both through the internal self-organization of land consolidation actors and through general functioning rules (stated by the law) and by market institutions as well.

The informational function of the institutions is determined by its ability to transmit to the land consolidation actors the information about the rules and regulations, the use of which will con-tribute to the formation of a positive effect in their activities. Under the conditions of the obvious lack of information the institutions reduce the uncertainty in order to choose in land consolidation sphere. The lack of information leads to uncertainty of choice and can cause great loss of the re-sources while making this choice. The institutions help land consolidation actors to find new sources of available resources, to save them while choosing, and to apply effective technologies.

The institution function of the development and accumulation defines the rules of activity and interaction of those land consolidation stakeholders who have common objectives, use the same methods and ways of their achievement or coordination. The changing of objectives, reviewing its relevance and also the transformation of their technologies achievements result in a qualitative change of institutions. 


\section{Theory of the institutional environment}

The effectiveness of any system is defined with the development of an institutional environment. In economics the institutional environment is considered as the elaboration of basic political, social, legal and economic rules to which human behaviour must conform in order to receive basis for the production, exchange and distribution (FAO, 2008). Thus, the institutional environment is a distinct set of different institutions which define the framework of functioning and development of economic actors.

The development of institutional environment of the agricultural land consolidation in Ukraine may be favourable under the condition of adjustment of institutional interests of the actors and agents of the institution.

The contradictions arising within the institution are the impulse for its improvement and are solved at the following levels: at the first level - in the case of disagreements in agents' interests within the general interest of institutional subject it is needed to eliminate special, unusual forms and methods of economic interactions or to separate different interests to another groups of interest; at the second level it is reasonable to fix new rules or regulations within the individual community of land consolidation participants if the localization of some specific forms of cooperation is found. Thus, there are two possible options for solving contradictions: 1 ) the rejection of the rules and regulations which in the process of testing were false; 2) the final fixing of their rules and regulations as formal ones that guarantee the effective relationships between land consolidation actors. The third level is the opposition of the parties and the formation of a new institution.

The development of institutional environment is defined with quantitative and qualitative characteristics of the institutions. Therefore, in making the institutional environment of the land consolidation system it is necessary to find the answers to a number of questions: 1) how many institutions there should be to optimize the functioning of such a system; 2) the set analysis of which the institutions guarantees a proper understanding of the essentiality and content of the land consolidation system; 3) how many actors have to interact in order the institute become a full-fledged one. The rules that are used in the relations between the actors become an institute only when the majority follows it.

The level of validity of institutionalization in the relations concerning transaction costs is a key element to ensure the optimality of institutional environment. In other words it is the value of the resources required for the creation and use of the institutions (Melnyk et al., 2011).

The institutional environment is always changing due to the institutional changes caused with the mismatch between the existing institutions, modified conditions and the environment. The changes in the institutional environment are based on the implementation of institutional technology. The institutional technology is the technology related with the generating (designing, projecting) and also the importing of the new institutions that can provide reducing of transaction costs for implementation of the agricultural land consolidation (Melnyk et al., 2011).

Fig. 1. The structure of the institutional environment of agricultural land consolidation*

The author's own work

CASUAL COMPONENT:

Land Use

2. The System of Agricultura

Production

3. Consequences of Land Reform 


\section{The institutional environment of agricultural land consolidation}

In our opinion, the main components of the concept "Institution of agricultural land consolidation" are: traditional and mental, legal, causal (cause-effect), organizational, structural, and procedural (Popov, 2013). The components of the "Institution of agricultural land consolidation" in the institutional environment are presented as a system of the institutes or the certain factors. The inter-consistency of these institutions creates an institutional environment for the development of agricultural land consolidation. With the purpose to better systematize the institutes that form the institutional environment of agricultural land consolidation we developed a scheme (Fig. 1) based on the mentioned above basic components.

\subsection{The Legal Component}

The Legal Component of the institutional environment of land consolidation is represented with the system of two major institutes of Legal Security and Land Property Rights. The Institute of Legal Security at the legislative level determines the legal principles of land consolidation, its actors and objects, general legal responsibility for providing land consolidation. It should be clarified what land concerns to consolidation, only agricultural or forest, water and urban. The legislation should necessarily determine: what methodological approaches of land consolidation can be used and in what cases; is the voluntary land amalgamation belongs to land consolidation or not; in what cases it is necessary to carry out comprehensive (compulsory) land consolidation; whether the special law on land consolidation is needed; objectives and levels of providing land consolidation; whether the land consolidation procedure is considered as a specific event or as land management (cadastral) activities.

The Institute of Land Property Rights relates to the transformation of property relations regarding land ownership, their legal regulation, achieving a certain balance between the freedom of a land owner and public interest in the use of the land during the providing of land consolidation. Land legislation supporting the structural changes, measures concerning nature protection and a sustainable land management; monitoring the using of natural resources and environment.

The Institute of Land Property Rights will inevitably influence the social conditions of a modern village; it will change the traditional forms of functioning and traditional way of life in its various manifestations.

\subsection{The Organizational and Structural Component}

Organizational and Structural Component includes such institutions as the Executive Authority, the Land Owners/ Users, Civil Society (non-governmental organizations NGOs), the Financial and Economic Management (stimulation).

The Institute of Executive Authority consists of the central office agencies such as: the Ministry of Agriculture and Food, the Ministry of Justice, the Ministry of Environment, the Ministry of Infrastructure, the Ministry of Social Policy, the Departments of State Land Cadastre, Land Management, Registration and others. This institute represents the executive authorities and their ac-ceptance of responsibility for the participation in the implementation of land consolidation according to the levels of providing: national, regional or local (Popov, 2013). The institute of Land Owners/Users includes all owners and users of the land parcels interested in land consolidation and those who relate to its implementation. Landowners and land users can represent their interests individually or collectively by creating different committees or associations. The Civil Society Institute involves non-governmental organizations participating and monitoring the process of land consolidation from the public point of view. These ones include local communities or their representatives, various associations of farmers, entrepreneurs, producers, environmental protection and others. The role of private organizations in land consolidation participating procedure and the possibility of state-private partnership creating should be identified and regulated. The Institute for Financial and Economic Management comprises measures to encourage the land consolidation providing with reducing the fees, giving tax benefits, improving conditions for easy access to subsidies and loans, exemption for a period of taxes and so on.

\subsection{The Procedural Component}

The Procedural Component of institutional environment of land consolidation involves a set of institutions such as: State Land Cadastre, Land Management, Registration of Property Rights and Land Mobility (market). The Institutes of State Land Cadastre, Land Management, and Registration of Property Rights provide timely the legal definition and establishment of land parcel boundaries, land readjustment procedures, the legal status of land parcels, including the right to lease, mortgage, servitudes or restrictions (encumbrances) to land. Cadastral and registration systems must provide the basis for identifying the rights of the holders and landowners. The quality of procedures and project development of land consolidation directly depends on the quality of the maintenance of the land cadastre and registration system - that is on the efficiency of providing reliable, objective, accurate and detailed information concerning the present land use of consolidation territory. The Institute of Land Mobility includes: Land Bank, Land Exchange, land registration and cadastral systems, credit institutions, licensed land management and land evaluation organizations (public and/or private). The land mobility in land consolidation projects is defined as the coordinated social relations extent of land rights re-structuring through the sale, purchase, exchange or lease from one owner to another as it proves possible during the re-allotment process.

In general, institutional frameworks of modern agricultural land consolidation should be based on the establishing of causal (cause-effect) relationships between 
the problem of land fragmentation and a sustainable rural development, as well as the improvement of institutions and technology management.

The effectiveness of land consolidation procedure can be achieved only if the feedback will be "land consolidation actors - land consolidation object". In other words, the land consolidation actors have to get information about the achievement (or no achievement) effect from the land consolidation object, appreciate it and adjust their own decision to the fact that the system can function in a given mode. It should be noted that feedbacks are the essence of the cause-effect relationship characterized with the fact that the result of previous actions influence the next management decision about the implementation of land consolidation. Without such communication, without obtaining the information from the land consolidation object as to the previous effect the consolidation actor could strengthen the destructive impact of the land consolidation system.

\subsection{The Casual Component}

The knowledge of causal relationships about land consolidation allows to expose the essence of the processes and on this basis to give a correct assessment of the results achieved in the current situation, identifying the potential for increasing efficiency of measures, and justifying plans (schemes, projects) and administrative decisions.

Without studying causal relationships the overall picture of the investigated object breaks up into separate parts and internal and external communications are lost. Therefore, it is impossible to predict and evaluate the consequences of administrative actions on land consolidation results.

The causal relationship is a stable unchanged and regular one. The efficiency of land consolidation is based on identifying, measuring and understanding these relationships. The classification, systematization, modelling and measurement of causal relationships are major methodological issues of land consolidation. Only with understanding causal relationships of different activities it is possible to identify by which factor or managerial influence (type and methodical approach of land consolidation, its efficiency, the amount of income received by landowners/users, environmental and social indicators etc.) will change the final results after land readjustment, and on this basis to justify any decision of land consolidation.

\subsection{The Traditional and Mental Component}

It is known that the historical customs, traditions and mental features have a significant impact on the willingness of the population and the executive authorities on the development and effectiveness of land consolidation implementation. Therefore, Traditional and Mental Component is an integral part of the institutional environment of land consolidation. Traditional and Mental Component consists of: valuable and motivational characteristics of the social community; the system of the elements of spiritual life and the world view that defines the appropriate behavioural patterns, activities, lifestyle of different social groups and individuals; the set of values, symbolic, conscious or subconscious feelings, ideas, attitudes, beliefs and worldview. Therefore, considering these factors it is necessary to use different methods of working with land consolidation actors in the different regions - land consolidation procedure must consider the peculiarities of the regions in Ukraine, because Ukraine is quite heterogeneous in natural conditions, history, traditions and mentality of people. So, the land consolidation rules that are inherent in the east or southeast of Ukraine can not be carried on to western Ukraine and vice versa. At the same time, land consolidation providing at a regional level should not be directed in favour of some regions and to the detriment of others be-cause the regions of Ukraine are not separated, they are united, complementary and mutually enrich each other as the whole.

\section{Findings}

It is important to take into account the presence of financial resources and human capacity for successful implementation of land consolidation. Land consolidation designers should be able to use the experience of similar reforms in other countries. Finally, we need a strong political will and support of the people.

Today, there is a real distrust in the government initiates. There is a fear of losing land parcels due to the land readjustment (re-allotment). Moreover the rejection of the market mechanism for the land mobility (including the agricultural land) can be a significant obstacle for the development of land consolidation. We should remember that the land consolidation procedure must be accessible, understandable, transparent, as simple as possible and suitable to use.

In Ukraine the urgent task is particularly not only to create, design and import of land consolidation institutions but also to provide the diagnostic of their maturity and suitability for the cur-rent level of land consolidation relations. Therefore, in Ukrainian realities of the development of a new land consolidation system a special attention should be paid to the creating of an instrument for monitoring the effectiveness of institutions, fixing them in daily land consolidation actors' livelihoods and timely replacement according to the changes in land consolidation strategy due to the globalization and integration processes. The national experience shows the importance of this approach because the introduction of the institution in the economic life does not guarantee its viability, incorporation and compliance. This is confirmed by the fact that even under the existing legislative framework of land tenure in Ukraine landowners, land users, an agricultural farm, and different companies often ignore the formal rules. Thus, the establishment and improvement of the institutional environment is related to the process of institutionalization, which consists of the unity of the following components: in the short term the declaration by law specific rules and regulations of 
behaviour of land consolidation actors; in the long run legitimization and public recognition, fixing of this recognition in "unwritten" rules and within the individual and social behaviour.

The formation of a modern institutional environment of land consolidation should create favourable conditions for the attracting domestic and foreign investments, further economic structuring of the agricultural sector, and the reduction of regional asymmetries of socio-economic development. The realization of economic, social and environmental priorities at the local, regional and national level will depend on the usefulness of individual units (institutions) of institutional environment of land consolidation.

\section{Conclusions}

The main criterion of agricultural land consolidation development in Ukraine is a stable institutional regulation the ability to perform the functions of regulation for a long time. In our opinion, the institutional environment of agricultural land consolidation should be considered primarily as a regulatory system harmonizing relations of the agricultural production, social and natural re-sources, designed to optimize the production, based on the actual requirements and restrictions of the existing institutes and institutions to guarantee a rational use of land resources. The specific methodological base of institutional environment of land consolidation is the implementation of the principles of a sustainable development.

Thus, the main directions of institutional system of agricultural land consolidation at present include: 1) development of institutions of state intervention and regulation of land consolidation; 2) improvement of land market mechanisms, lease relations, mortgage, and sale; 3) development of institutions focused on social services; 4) innovation through investment in the economy; 5) establishment of the formal framework for land consolidation procedure with the aim to guarantee its open and transparent implementation and to control the land consolidation actors; 6) development of financial mechanism and infrastructure of land consolidation.

\section{References}

Van Dijk, T. (2002, April). Central European Land Fragmentation in the Years to Come - A Scenario Study into the Future Need for Land Consolidation in Central Europe. Paper presented at FIG XXII International Congress, Washington, D.C., USA. [Electronic resource]. - Retrieved from: https://www.fig.net/resources/proceedings/ fig_proceedings/fig_2002/TS7-16/TS7_16_vandijk.pdf

Van Dijk, T. (2004). Land consolidation as Central Europe's Panacea reassessed. In: Proceedings of Symposium on Modern Land Consolidation, September 10-11, Volvic (Clermont-Ferrand), France. [Electronic resource]. Retrieved from: http://www.fig.net/commission7/france_2004/papers_symp/ts_01_vandijk.pdf

FAO. (2003). Opportunities to mainstream land consolidation in rural development programmes of the European Union. Land Tenure Policy Series, Rome.

Kilochko, V.M. (2009). Zemelna reforma i neobhidnist konsolidatsii zemel u silskomu gospodarstvi. Zemleustrii i kadastr, 2, p. 18-20.

Martyn, A. (2011). Konsolidatsija zemel silskogospodars'kogo priznachennja v Ukraini: mehanizm zdiysnennja. [Electronic resource]. - Retrieved from: http://zsu.org.ua/andrij-martin/92-2011-06-14-08-46-34

Melnyk, A.F., Vasina, A.Ju., Zheljuk, T.L, Popovich, T.M, (2011). Natsionalna ekonomika. Kyiv: Znannja.

Popov, A.S. (2013). Instytutsiyni zasadi konsolidatsii zemel silskogospodars'kogo priznachennja. Naukovi pratsi Donetskogo natsionalnogo tehnichnogo universytetu, Serija: «Girnicho-geologichna», 1(18), p. 271-277.

Sonnenberg, J. (2002, April). Fundamentals of Land Consolidation as anInstrument to Abolish Fragmentation of Agricultural Holdings. Paper presented at FIG XXII International Congress Washington, D.C. USA. [Electronic resource]. - Retrieved from: www.fig.net/pub/fig_2002/TS7-4/TS7_4_sonnenberg.pdf

Thomas, J. (2004, September). Modern Land Consolidation - recent trends on land consolidation in German. Paper presented at FIG Commission VII-Symposium, Volvic, France. [Electronic resource]. - Retrieved from: www.fig.net/commission7/france_2004/papers_symp/ts_03 thomas.pdf

Thomas, J. (2006, October). What's on Regarding Land Consolidation in Europe? Paper presented at XXIII FIG Congress, Munich, Germany. [Electronic resource]. - Retrieved from: www.fig.net/pub/fig2006/ papers/ts80_03 thomas_0311.pdf

Tkachuk, L.V. (2009). Konsolidatsija zemel: efektyvne vikorystannja ta ohorona v umovah transformatsii zemelnyh vidnosyn. Lviv: Vyd-vo Lvivskogo NAU.

Tretyak, A.M. (2002). Teoretichni osnovy zemleustroju. Kyiv: IZU UAAN.

Vitikainen, A. (2004). An Overview of Land Consolidation in Europe. Nordic Journal, 1, p. 25-44.

Shvorak, A.M. (2008). Teoretychni osnovy konsolidatsii zemel: zmist, meta, zavdannja, printsipy. Zemleustrii i kadastr, 4, p. 11-13. 


\section{Андрей ПОПОВ}

\section{ФОРМИРОВАНИЕ ИНСТИТУЦИОНАЛЬНОЙ СРЕДЫ КОНСОЛИДАЦИИ ЗЕМЕЛЬ СЕЛЬСКО-} ХОЗЯЙСТВЕННОГО НАЗНАЧЕНИЯ В УКРАИНЕ

Аннотация. Каждая теория требует прикладных инструментов. Консолидация земель является многодисциплинарным инструментом устойчивого развития сельских районов, который на основе своей динамической структуры предоставляет возможности для принятия наиболее лучших вариантов решения вопросов по управлению земельными ресурсами. Именно поэтому главной идеей статьи есть теоретическое обоснование и разработка научно-практических рекомендаций по формированию институциональной среды консолидации земель сельскохозяйственного назначения в Украине. Предметом исследования выступает процесс формирования консолидации земель сельскохозяйственного назначения. Методология. В процессе исследования использованы следующие методы: диалектический, абстрактно-логический и системного анализа (теоретические и методологические обобщения, определение сущности содержания институциональной среды консолидации земель сельскохозяйственного назначения). В статье рассматривается роль институтов в экономическом развитии и представлена характеристика их функций таких как: регулятивной, регламентной, распределительной, информационной, развития и накопления. Как элементы новизны предложена и предоставлена подробная характеристика основных составляющих институциональной среды консолидации земель: традиционно ментальная, правовая, причинно-следственная, организационно-структурная, процессуальная. Представлено содержание институтов каждой из этих составляющих и их значения и взаимосвязи. Теоретически исследовано, что формирование институционального механизма консолидации должно быть симбиозом как традиционных, так и рыночных институтов на демократических началах с участием общины. В статье акцентируется внимание на целесообразности формирования механизма мониторинга эффективности институтов. Результат. Автор предлагает рассматривать институциональную среду консолидации земель сельскохозяйственного назначения как регуляторную систему гармонизации взаимоотношений сельскохозяйственного производства, социальных и природных ресурсов, направленную на оптимизацию производства с учетом фактических требований и ограничений действующих институтов и институтов по обеспечению рационального использования земельных ресурсов. Практические последствия. Анализ сложившейся ситуации в Украине показывает, что неотложной задачей является не только создания, проектирования, импорт институтов, но и диагностирования их зрелости и пригодности для сложившегося уровня развития отношений по консолидации земель. Это положение подтверждается отсутствием специальной государственной политики по развитию консолидации земель и существующим недоверием по отношению мероприятий проводимых правительством. Также, автором предлагается целый ряд необходимых действий для развития консолидации земель сельскохозяйственного назначения. 